\title{
Diffuse Type Adenocarcinoma
}

National Cancer Institute

\section{Source}

National Cancer Institute. Diffuse Type Adenocarcinoma. NCI Thesaurus. Code C4127.

An adenocarcinoma characterized by the presence of a diffuse cellular infiltrate which is composed of poorly cohesive cells with minimal or no glandular formations.

Representative example is the gastric diffuse adenocarcinoma. 